\title{
Skrining fitokimia dan uji toksisitas ekstrak daun balik angin (Mallotus Sp) terhadap larva Artemia salina Leach dengan metode brine shrimp lethality test (BSLT)
}

\author{
Anderson Arnold Aloanis ${ }^{* a}$, Fahriana $^{b}$, Haryadi $^{b}$ \\ a Ilmu Kimia FMIPA, Universitas Negeri Manado, Tondano, 95619, Indonesia \\ ${ }^{b}$ Farmasi, Universitas Kristen Indonesia, Tomohon, 95441, Indonesia
}

\begin{tabular}{l} 
I N F O A R T I K E L \\
\hline Diterima 8 September 2017 \\
Disetujui 9 Oktober 2017 \\
\\
\hline Key word: \\
Balik angin (Mallotus sp), \\
phytochemical screening, \\
BSLT. \\
\hline Kata kunci: \\
Balik angin (Mallotus sp), \\
Skrining fitokimia, \\
BSLT.
\end{tabular}

${ }^{*} e$-mail:

andersonaloanis@unima.ac.id

*Telp:

\begin{abstract}
A B S T R A C T
One of the plants that are used to regular treatment is behind the wind (Mallotus sp.). Traditionally this is used for the relief of pain and increase stamina by way of boiling the seven pieces of young leaves and drink once a day in the morning. This research aims to know the acute toxicity of ethanol extracts of leaves behind the wind (Mallotus sp) against larvae of Artemia salina Leach BSLT method. The research method used is qualitative analysis of chemical compound and Brine Shrimp Lethality Test (BSLT) method with post-test-only control group design. The results of research on ethanol extracts of leaves behind the wind showed the value of LC 50 of $32.061 \mathrm{ppm}$, so can be said of ethanol extracts of leaves behind the wind on this experiment of acute toxicity has on the larvae of Artemia salina Brine Shrimp method using Leach Lethality Test (BSLT).
\end{abstract}

\begin{abstract}
A B STRAK
Salah satu tanaman yang biasa di manfaatkan untuk pengobatan adalah Balik angin (Mallotus sp). Secara tradisional tanaman ini biasa dimanfaatkan untuk menghilangkan nyeri dan menambah stamina dengan cara merebus tujuh lembar daun muda dan diminum sekali sehari di pagi hari. Penelitian ini bertujuan Untuk mengetahui kandungan kimia dan toksisitas akut dari ekstrak etanol daun balik angin (Mallotus sp) terhadap larva Artemia salina Leach menggunakan metode BSLT. Metode penelitian yang digunakan adalah analisis kualitatif kandungan kimia senyawa dan Brine Shrimp Lethality Test (BSLT) dengan pendekatan post-test-only control group design. Hasil penelitian terhadap ekstrak etanol daun balik angin menunjukan nilai LC50 sebesar 32,061 ppm, sehingga dapat dikatakan ekstrak etanol daun balik angin pada percobaan ini memiliki toksisitas akut pada larva Artemia salina Leach menggunakan metode Brine Shrimp Lethality Test (BSLT).
\end{abstract}

\section{Pendahuluan}

Masyarakat Indonesia sering memanfaatkan tanaman herbal untuk pengobatan tradisional. Hal ini dikarenakan tanaman herbal memiliki keuntungan, antara lain lebih murah, lebih mudah diproduksi, serta lebih mudah diperoleh dan memiliki efek samping yang rendah.
Salah satu tanaman yang biasa di manfaatkan untuk pengobatan adalah Balik angin (Mallotus sp). Secara tradisional tanaman ini biasa dimanfaatkan untuk menghilangkan nyeri dan menambah stamina dengan cara merebus tujuh lembar daun muda dan diminum sekali sehari di pagi hari [1]. 
Hasil penelitian pendahuluan yang telah dilakukan oleh peneliti yaitu berupa skrining fitokimia, diketahui bahwa tanaman balik angin (Mallotus sp) mengandung beberapa senyawa metabolit sekunder antara lain tanin, alkaloid, flavonoid, dan steroid.

Salah satu tumbuhan dari genus Mallotus, yaitu Mallotus Philippinenssis mengandung senyawa golongan, kardenolida, triterpenoid, steroid, dan komponen fenolik [2]. M.Philippinenssis perpotensi sebagai antivirus, antifertilitas, antibakteri dan antijamur, antiinflamasi dan immunoregulator, antioksidan dan anti radikal bebas, inhibisi protein pada proses terjadi kanker, hepatoprotektif, antikestodal, pencahar dan obat cacing, anti-TBC, antileukimia, antiproliferatif, anti-HIV, antialergi, antitumor, dan toksisitas.

Dalam mempelajari toksisitas yang paling awal dilakukan adalah dengan menggunakan kematian dari hewan percobaan sebagai suatu respon dari pengaruh suatu senyawa yang diuji. Uji toksisitas larva udang merupakan salah satu pengujian toksisitas yang cepat, aman, praktis dan ekonomis untuk skrining, fraksinasi, dan penentuan bioaktivitas senyawa bahan alam.

\section{Bahan dan Metode}

Bahan yang digunakan dalam penelitian adalah daun balik angin yang diperoleh dari Ternate kec. Jailolo Desa Tedeng, telur Artemia Salina, air laut, dan etanol $70 \%$, kloroform amoniakal, $\mathrm{FeCl}_{3}$, serbuk $\mathrm{Mg}, \mathrm{CH}_{3} \mathrm{COOH}$ glasial, $\mathrm{H}_{2} \mathrm{SO}_{4}$ pekat, $\mathrm{NaOH}, \mathrm{HCl} 2 \mathrm{~N}$, Reagen Wagner.

Penelitian ini merupakan eksperimental dengan pendekatan posttest-only control group design di Laboratorium dengan perlakuan pemberian ekstrak etanol daun balik angin (Mallotus sp) terhadap larva Artemia salina Leach dengan metode Brine Shrimp Lethality Test (BSLT).

\section{Ekstraksi}

Sampel daun balik angin dibersihkan dan dikering anginkan kemudian Sampel daun balik angin yang sudah kering dihaluskan sampai menjadi serbuk. Serbuk kering daun balik angin dimaserasi dengan etanol 70\%. Proses maserasi dilakukan selama 3 × 24 jam. Ekstrak kemudian disaring untuk mendapatkan filtrat dan residu. Maserat yang dihasilkan disaring, dikumpulkan dan diuapkan dengan rotary evaporator, sehingga diperoleh ekstrak kental daun balik angin.

\section{Skrining fitokimia}

Sampel yang digunakan untuk skrining fitokimia adalah ekstrak etanol daun balik angin.

\section{Uji Alkaloid}

Sebanyak 2 gram sampel diekstraksi dengan kloroform amoniakal sebanyak $5 \mathrm{~mL}$. Ekstrak dimasukan kedalam tabung reaksi sebanyak 10 tetes. Kemudian tabung reaksi ditambahkan $\mathrm{H}_{2} \mathrm{SO}_{4} 2 \mathrm{~N}$ sebanyak 2 tetes lalu dikocok kuat. Kemudian di tambahkan pereaksi wagner pada tabung reaksi. Pada pereaksi wagner akan terbentuk endapan kuning yang menandakan positif adanya alkaloid [3].

\section{Uji Flavonoid}

Sebanyak $2 \mathrm{~mL}$ ekstrak ditambahkan dengan air panas secukupnya, kemudian dididihkan selama 5 menit lalu disaring. Filtrat sebanyak 5 $\mathrm{mL}$ ditambahkan 0,05 mg serbuk $\mathrm{Mg}$ dan $1 \mathrm{~mL}$ $\mathrm{HCl}$ pekat, kemudian dikocok kuat-kuat. Uji positif ditunjukkan dengan terbentuknya warna merah, kuning atau jingga [3].

\section{Uji Tanin}

Sebanyak $1 \mathrm{~mL}$ ekstrak ditambahkan dengan beberapa tetes larutan besi(III)klorida 10\%. Jika terjadi warna biru tua atau hitam kehijauan menunjukkan adanya tannin [4].

\section{Uji Steroid dan Triterpenoid}

Sebanyak $2 \mathrm{~mL}$ ekstrak ditambahkan $\mathrm{CH} 3 \mathrm{COOH}$ glasial sebanyak 10 tetes dan $\mathrm{H} 2 \mathrm{SO} 4$ pekat sebanyak 2 tetes. Larutan dikocok perlahan dan dibiarkan selama beberapa menit. Adanya steroid ditunjukan oleh warna biru atau hijau, sedangkan triterpenoid memberikan warna merah atau ungu [3].

\section{Uji Saponin}

Sebanyak 2-3 mL ekstrak dimasukkan ke dalam tabung reaksi, kemudian ditambahkan 10 $\mathrm{mL}$ air panas lalu didinginkan, kemudian dikocok 
kuat-kuat selama 10 detik lalu ditambahkan 1 tetes $\mathrm{HCl} 2 \mathrm{~N}$. Uji positif ditunjukkan dengan terbentuknya buih yang stabil setinggi $1-10 \mathrm{~cm}$ selama tidak kurang dari 10 menit [4].

\section{Uji Toksisitas Menggunakan Metode BSLT}

Sampel yang digunakan untuk uji toksisitas adalah ekstrak etanol daun balik angin. Masingmasing pengujian dibuat dua kali pengulangan.

\section{Penyiapan Larva Artemia Salina}

Penyiapan larva udang dilakukan dengan mengambil telur Artemia Salina ditimbang sebanyak $100 \mathrm{mg}$. Penetasan dilakukan dengan cara merendam telur tersebut dalam air laut sebanyak $500 \mathrm{~mL}$ dan diberi penerangan serta diaerasi.

\section{Penyiapan Larutan Stok}

Untuk pembuatan larutan stok, ekstrak ditimbang sebanyak $200 \mathrm{mg}$ kemudian dilarutkan sampai $100 \mathrm{~mL}$ dengan air garam, kemudian dari larutan stok 2000 ppm dibuat pengeceran 100, 50, 25, dan 12,5 $\mu \mathrm{g} / \mathrm{mL}$. Untuk Kontrol (0 ppm) dilakukan tanpa penambahan ekstrak.

\section{Uji Toksisitas}

Perlakuan uji toksisitas dilakukan pada ekstrak kental daun balik angin. Disiapkan 6 wadah dan 1 wadah sebagai kontrol. Selanjutnya pada tiap konsentrasi larutan dimasukan 10 ekor larva udang Artemia salina. Pengamatan dilakukan selama 1 × 24 jam terhadap kematian larva udang dimana setiap konsentrasi dilakukan dua kali pengulangan dan dibandingkan dengan kontrol [5].

\section{Analisis Data}

Data hasil penelitian uji toksisitas diolah dengan analisis probit menggunakan SPSS 20.0 untuk mengetahui harga LC50.

\section{Hasil dan Pembahasan}

Pada penelitian ini simplisia daun balik angin sebanyak 990 gram dimaserasi selama $3 x$ 24 jam dengan meggunakan pelarut etanol 70\%, dan didapatkan filtrat sebanyak $9.790 \mathrm{~mL}$. Filtrat kemudian disaring menggunakan kertas saring lalu dimasukan kedalam alat rotary evaporator untuk memisahkan ekstrak yang masih tercampur dengan pelarut sehingga didapatkan ekstrak kental yang akan digunakan untuk uji BSLT terhadap larva Artemia salina Leach. Pada proses evaporasi menggunakan rotary evaporator digunakan vacum sebesar $175 \mathrm{Mbar}$, rotasi $60 \mathrm{rpm}$ dan suhu $40^{\circ} \mathrm{C}$. lalu didapatkan ekstrak kental etanol daun balik angin (Mallotus sp) sebanyak 146,9 gram.

Dari hasil ekstraksi dengan menggunakan metode maserasi didapatkan rendemen ekstrak dengan cara sebagai berikut:

\section{Skrining Fitokimia}

Hasil uji alkaloid dari ekstrak daun balik angin menandakan positif pada pereaksi wagner dengan adanya endapan berwarna kecoklatan. Alkaloid mengandung atom nitrogen yang bersifat basa dan merupakan bagian dari cincin heterosiklik. Alkaloid mempunyai kegiatan fisiologis yang menonjol dan sering digunakan secara luas dalam bidang pengobatan. Alkaloid merupakan senyawa yang mempunyai satu atau lebih atom nitrogen biasanya dalam gabungan dan sebagian dari sistem siklik [3]. Hasil uji tanin ekstrak etanol daun balik angin positif tanin karena terbentuk warna hijau kehitaman. Tanin mampu mengikat protein, selain mampu mengikat protein tanin juga bersifat melindungi protein dari degradasi enzim mikroba maupun enzim protease pada tanaman [6]. Pada uji flavonoid diketahui ekstrak etanol daun balik angin terbentuk warna merah yang menandakan positif adanya flavonoid. Hasil uji triterpenoid pada ekstrak etanol daun balik angin tidak terbentuk warna merah, sedangkan pada uji steroid positif karena terbentuk warna hijau. Senyawa golongan steroid digunakan luas dalam dunia pengobatan dan kontrasepsi antara lain: androgen merupakan hormon steroid yang dapat menstimulasi organ seksual jantan, estrogen dapat menstimulasi organ seksual betina, adrenokortikonoid dapat mencegah peradangan dan rematik [7]. Hasil uji saponin pada ekstrak daun balik angin negatif karena tidak terbentuk busa. 
Tabel 1. Hasil skrining ekstrak etanol daun balik angin (Mallotus sp)

\begin{tabular}{|c|c|c|c|}
\hline $\begin{array}{c}\text { Kandunga } \\
\text { n Kimia }\end{array}$ & $\begin{array}{c}\text { Metode } \\
\text { Pengujia } \\
\mathbf{n} \\
\end{array}$ & Hasil & $\begin{array}{c}\text { Ket } \\
\text {. }\end{array}$ \\
\hline Alkaloid & $\begin{array}{l}\text { Pereaksi } \\
\text { Wagner }\end{array}$ & $\begin{array}{l}\text { Terbentuk } \\
\text { endapan }\end{array}$ & + \\
\hline Tanin & $\mathrm{FeCl}_{3}$ & $\begin{array}{l}\text { Terbentuk } \\
\text { warna hijau } \\
\text { kehitaman }\end{array}$ & + \\
\hline Flavonoid & $\mathrm{NaOH}$ & $\begin{array}{l}\text { Terbentuk } \\
\text { warna } \\
\text { merah }\end{array}$ & + \\
\hline $\begin{array}{l}\text { Triterpenoi } \\
\text { d }\end{array}$ & Uji LB & $\begin{array}{l}\text { Tidak } \\
\text { terbentuk } \\
\text { warna } \\
\text { merah atau } \\
\text { ungu }\end{array}$ & - \\
\hline Steroid & Uji LB & $\begin{array}{l}\text { Terbentuk } \\
\text { warna hijau }\end{array}$ & + \\
\hline Saponin & $\mathrm{HCl} 2 \mathrm{~N}$ & $\begin{array}{l}\text { Tidak } \\
\text { terbentuk } \\
\text { busa }\end{array}$ & - \\
\hline
\end{tabular}

\section{Uji Toksisitas Metode BSLT}

Total larva yang digunakan pada tiap-tiap konsentrasi sebanyak 10 ekor dengan 2 kali pengulangan. Sehingga total larva yang digunakan pada seluruh percobaan adalah 100 ekor. Total kematian diperolah dengan menjumlah kematian larva pada setiap konsentrasi. Berdasarkan Tabel 2, maka terdapat hubungan antara konsentrasi ekstrak dengan total kematian larva. Berikut disajikan dalam bentuk grafik.

Berdasarkan grafik diatas, menunjukkan bahwa jumlah kematian larva pada konsentrasi $12,5 \mu \mathrm{g} / \mathrm{mL}$ adalah $35 \%$ sedangkan pada konsentrasi $25 \mu \mathrm{g} / \mathrm{mL}$ sebanyak 50\%, hal ini menunjukkan peningkatan kematian larva sebesar $15 \%$. Lalu pada konsentrasi $50 \mu \mathrm{g} / \mathrm{mL}$, total kematian larva yaitu $60 \%$. Lalu pada konsentrasi $100 \mu \mathrm{g} / \mathrm{mL}$ angka kematiannya sebesar $85 \%$, sehingga terdapat peningkatan kematian larva sebesar $25 \%$. Sehingga dapat disimpulkan bahwa peningkatan konsentrasi yang semakin tinggi akan meningkatkan kematian larva.

Tabel 2. pengaruh berbagai konsentrasi ekstrak etanol daun balik angin(Mallotus sp) terhadap larva Artemia salina Leach.

\begin{tabular}{|c|c|c|c|c|c|}
\hline \multirow[t]{2}{*}{ Replikasi } & \multicolumn{4}{|c|}{$\begin{array}{c}\text { Jumlah Kematian larva } \\
\text { Tiap Konsentrasi } \\
(\mu \mathrm{g} / \mathrm{mL})\end{array}$} & \multirow{2}{*}{$\begin{array}{c}\text { Kon }( \\
\quad \\
0\end{array}$} \\
\hline & 100 & 50 & 25 & 12,5 & \\
\hline 1 & 9 & 6 & 5 & 3 & 0 \\
\hline 2 & 8 & 6 & 5 & 4 & 0 \\
\hline $\begin{array}{l}\text { Total } \\
\text { Kematian }\end{array}$ & 17 & 12 & 10 & 7 & 0 \\
\hline Rata-rata & 8,5 & 6,0 & 5,0 & 3,5 & 0 \\
\hline $\begin{array}{l}\text { Persentase } \\
\text { Kematian }\end{array}$ & $85 \%$ & $60 \%$ & $50 \%$ & $35 \%$ & $0 \%$ \\
\hline
\end{tabular}

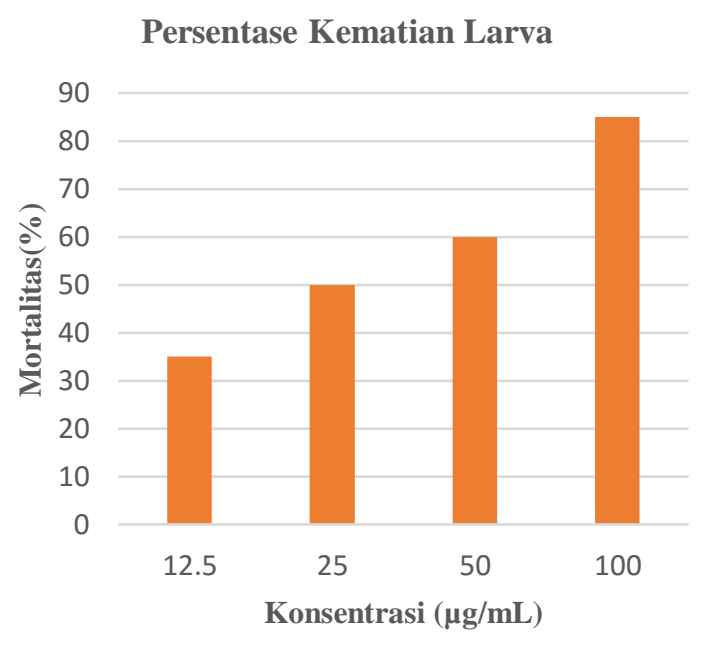

Gambar 1. Grafik Persentase Kematian Larva Artemia Salina Leach Pada Uji Toksisitas Ekstrak

Etanol Daun Balik Angin (Mallotus sp).

Berdasarkan Gambar 1, jumlah kematian larva terbanyak terdapat pada konsentrasi 100 $\mu \mathrm{g} / \mathrm{ml}$ hal ini sesuai dengan teori dimana semakin tinggi konsentrasi ekstrak maka semakin tinggi pula tingkat kematian larva [8]. 


\section{Penetapan $L C_{50}$}

Berdasarkan Gambar 2, dapat dikatakan bahwa data tersebut linear berdasarkan penarikan garis lurus dan didapatkan nilai $\mathrm{R}^{2}$ sebesar 0.928. Hasil analisis probit menunjukan nilai LC $_{50}$ dari ekstrak etanol daun balik angin sebesar $32,061 \mu \mathrm{g} / \mathrm{mL}$.

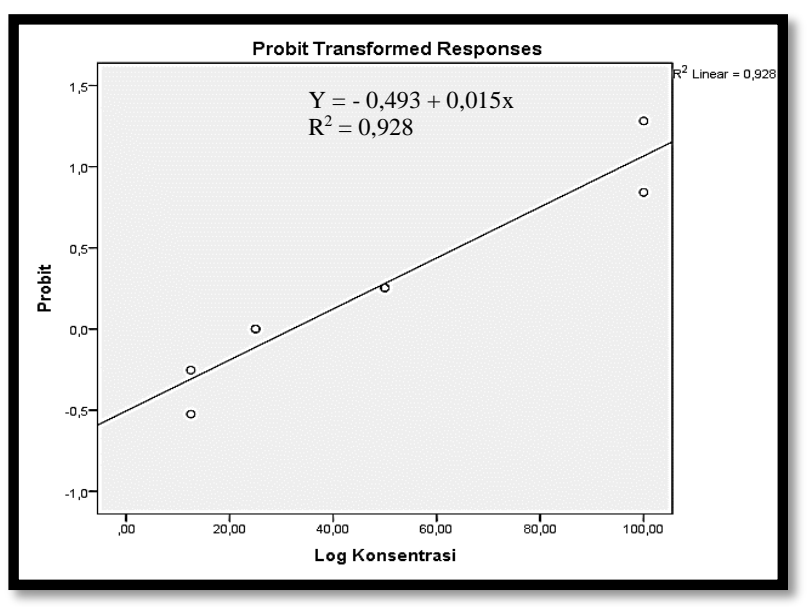

Gambar 2. Grafik analisis probit uji toksisitas ekstrak etanol daun balik angin (Mallotus sp) terhadap larva Artemia salina Leach.

Hasil pengujian terhadap ekstrak etanol daun balik angin menunjukan nilai $\mathrm{LC}_{50}$ sebesar 32,061, sehingga dapat dikatakan ekstrak etanol daun balik angin pada percobaan ini memiliki toksisitas akut pada larva artemia salina Leach menggunakan metode BSLT.

\section{Kesimpulan}

Ekstrak etanol daun balik angin (Mallotus sp) memiliki toksisitas akut pada larva artemia salina Leach menggunakan metode BSLT dengan nilai LC50 sebesar 32,061 $\mu \mathrm{g} / \mathrm{mL}$.

\section{Daftar Pustaka}

1. Moumou, F.; Thomas, A. A.; Kainde, R. P.; Nurmawan, W., Pemanfaatan tumbuhan obat oleh masyarakat Desa Toliwang Kecamatan Kao Barat Kabupaten Halmahera Utara. COCOS 2015, 6, (12).

2. Gangwar, M.; Goel, R.; Nath, G., Mallotus philippinensis Muell. Arg (Euphorbiaceae): ethnopharmacology and phytochemistry review. BioMed research international 2014, 2014.

3. Harborne, J., Metode Fitokimia Penuntun Cara Modern Menganalisis Tumbuhan, Terbitan Kedua. Institut Teknologi Bandung 1987.

4. Kumar, R. S.; Venkateshwar, C.; Samuel, G.; Rao, S. G., Phytochemical screening of some compounds from plant leaf extracts of Holoptelea integrifolia (planch.) and Celestrus emarginata (Grah.) used by Gondu tribes at Adilabad District, Andhrapradesh, India. International Journal of Engineering Science Invention 2013, 2, (8), 65-70.

5. lestari, M. S.; Himawan, T.; Abadi, A. L.; Retnowati, R., Toxicity and phytochemistry test of methanol extract of several plants from Papua using Brine Shrimp Lethality Test (BSLT) Journal of Chemical and Pharmaceutical Research 2015, 7, (4), 866-872.

6. Oliveira, A. C. P.; Shinobu, C. S.; Longhini, R.; Franco, S. L.; Svidzinski, T. I. E., Antifungal activity of propolis extract against yeasts isolated from onychomycosis lesions. Memórias do Instituto Oswaldo Cruz 2006, 101, (5), 493-497.

7. Nogrady, T., Kimia Medisinal Pendekatan Secara Biokimia. Bandung: Institut Teknologi Bandung. Hlm 1992, 19-21.

8. Meyer, B.; Ferrigni, N.; Putnam, J.; Jacobsen, L.; Nichols, D. j.; McLaughlin, J. L., Brine shrimp: a convenient general bioassay for active plant constituents. Planta Med 1982, 45, (05), 31-34. 